\title{
About Intentions to Donate for Sustainable Rural Development: An Exploratory Study
}

\author{
Luis Pérez y Pérez $1,2, *$ and Pilar Egea ${ }^{3,4}$ (i) \\ 1 Agrifood Research and Technology Centre of Aragon (CITA), Montañana Avenue, 930, \\ 50059 Zaragoza, Spain \\ 2 Agrifood Institute of Aragon (CITA-University of Zaragoza), Montañana Avenue, 930, \\ 50059 Zaragoza, Spain \\ 3 Faculty of Economics and Business, University of Zaragoza, Gran Vía Street, 2, 50005 Zaragoza, Spain; \\ pegea@unizar.es \\ 4 Environmental Sciences Institute (IUCA), University of Zaragoza, Pedro Cerbuna Street, 2, \\ 50009 Zaragoza, Spain \\ * Correspondence: lperez@aragon.es
}

Received: 20 November 2018; Accepted: 28 January 2019; Published: 1 February 2019

check for updates

\begin{abstract}
The Theory of Planned Behaviour (TPB) was used to investigate factors affecting the intention of citizens to donate money altruistically for sustainable rural development projects in Spain. To achieve this aim, individuals' attitudes, subjective norms and perceived behavioural control have been considered; also, Azjen's model was further extended to include additional elements: Moral norms, past behaviour, knowledge and some background factors. Respondents completed an online questionnaire assessing domains elaborated in the extended TPB model. Hierarchical multiple regression analysis revealed support for the model. Attitudes, injunctive norms, perceived behavioural control, moral norms, past behaviour, crowdfunding knowledge, age and employment condition were found to have positive and significant influence on intentions to donate. Theoretical and applied implications of the results are discussed, highlighting important considerations for public policy.
\end{abstract}

Keywords: pro-rural behaviour; altruistic behaviour; money donation; theory of planned behaviour

\section{Introduction}

Depopulation is an important issue in European Union regions. 44 European regions (NUTS 2 level) have a population density lower than 50 inhabitants per square kilometre, mainly in Mediterranean countries such as Spain, Portugal, France, Italy and Greece.

Besides depopulation, aging and abandoned traditional crops in Spanish rural areas have become a real problem in most of them. For example, the regions of Castilla-la-Mancha, Castilla y León, Extremadura and Aragón have a population density between 26-28 inhabitants per square kilometre. Furthermore, in Aragón about 25 per cent of total surface has a density below 5 inhabitants per square kilometre and the ageing index in these areas is above 150 per cent, reaching up to 300 per cent in some regions (ageing index was calculated as population over 65 years old divided by population under 15). Hence, the promotion of sustainable development in rural areas is one of the priorities of the Rural Development Programmes of the EU Common Agricultural Policy (CAP) for 2014-2020, meanly through LEADER programmes (a development method to engage local actors in the design and delivery of strategies, decision-making and resource allocation for the development of their rural areas). However, apart from these public policies, there are local private initiatives whose aims are to contribute to rural sustainability and development. Usually citizens promote these initiatives based on altruistic pro-rural behaviour and connected to natural resource endowments. People contribute to the 
financing of such efforts through various mechanisms. This is true of websites devoted to financing and implementing initiatives such as recovering local grape varieties, abandoned olive or almond trees; adopting free-range hens; building an olive mill; transforming saffron or adopting a forest, to name but a few of those recently carried out in Spain.

In this paper, we investigate the factors that affect the intention of citizens to finance projects for sustainable rural development in Spain by altruistic monetary donations. The study has used an extension of the Theory of Planned Behaviour (TPB) [1] considering individuals' attitudes, subjective norms and perceived behavioural control, and including additional predictors: moral norms, past behaviour, knowledge and socio-economic characteristics of the individuals. The remainder of the paper is organised as follows: The TPB modelling is presented in Section 2. The material and methods are explained in Section 3, Section 4 shows the main results of the analysis and Sections 5 and 6 are devoted to the discussion of the results and to drawing some conclusions.

\section{The Theory of Planned Behaviour}

Predicting and explaining the behaviour of individuals can be done considering their psychological aspects. Thus, many authors have studied the psychological components that allow to understand the factors that lead people to have certain behaviours [2-6].

In order to analyse the intentions of citizens to donate altruistically for sustainable rural development, we used a theoretical framework based on social psychology models, but also including socioeconomic factors. Among the social psychology models, [1] the TPB today is one of the most popular for understanding and predicting human behaviour. Its popularity can be revealed by conducting a Google Scholar search for the keyword "theory of planned behaviour". From 510 citations between 1985 and 2000, the number of citations has grown steadily to 5830 in 2001-2010 and up to 17,900 between 2011 and 2018. The TPB is an extension of the Theory of Reasoned Action (TRA) $[7,8]$ which considers not only the attitudes and subjective norms, but also an additional variable, perceived behavioural control (PCB), which facilitates predicting the behaviour of individuals in some cases $[7,9,10]$.

Under the TPB, the immediate antecedent of a particular behaviour is the intention to perform it. Behavioural intentions constitute an indication of the extent to which people are willing to try to perform a particular behaviour (i.e., I intend to donate), while the particular behaviour is something people are currently performing (i.e., I have made a donation). Intention is assumed to capture the motivational factors that influence the behaviour. Following [1], the basic TPB postulates that intentions are determined by: (1) attitudes towards the behaviour (the attractiveness of the individual evaluation of a behaviour); (2) subjective norms (the individual perceived social pressure to perform or not the behaviour) and (3) perceived behavioural control (individual's perception of the ease or difficulty to perform the behaviour). According to Ajzen's TPB, the more favourable the attitude and subjective norms with respect to the behaviour and the greater the perceived behavioural control, the more likely it is that a person will have an intention to perform the behaviour under consideration $[1,11]$.

While TPB is useful in its original specification, [1] it was put forth that, after the examination of traditional TPB variables, the TPB can allow additional predictors if these additional constructs can capture a significant proportion of the variance in intention. In fact, the initial TPB model has been criticised throughout its life for insufficient predictive power, criticisms related fundamentally to the use of an inadequate number of variables capable of explaining the reasons that lead individuals to have certain behaviours [12-14]. This has led many analysts to modify the original theoretical model by adding to the basic explanatory variables (attitudes, subjective norms and PCB), additional variables that have been shown in some cases to have a certain explanatory capacity such as, for example, "past behaviour", "moral norms", "perceived moral obligation", "perception of ease of use", "capacity to reject" and others [15]. 
In particular, the TPB literature has split subjective norms into injunctive and descriptive norms. Injunctive norms reflect perceptions of what significant others think one ought to do, and descriptive norms reflect the perception of whether other people perform the behaviour [16].

Also, the model has been expanded to include some additional constructs such as moral norms or past behaviour [17]. On the one hand, moral norms are broadly defined as an individual's code of conduct. They reveal feelings about personal responsibility or duty to perform a given behaviour. As opposed to subjective norms, moral norms are personal and internalised [18]. On the other hand, past behaviour has been used in numerous extended TPB (ETPB) models. Some studies $[16,19]$ have found that this is the best predictor of future behaviour, stronger than either attitudes or PBC. In the reviewed studies of ETPB, it has been posited to be an important and independent predictor of behavioural intention to donate.

Furthermore, additional predictors of intention capturing some background factors (socio-economic and demographic features of citizens) mentioned by [1] have been introduced into the models to increase its predictive performance [20]. The usefulness of personality traits to explain pro-environmental behaviour for Spanish people had been proved recently by [21,22]. Following this trend, we extend the TPB model in order to include a new predictor: the self-reported knowledge on crowdfunding. Knowledge has been identified as a powerful predictor of behavioural intentions [23], and crowdfunding is one of the few ways in which citizens can contribute altruistically to the funding of sustainable rural development projects.

The TPB has been widely used to address the psychological component for understanding the factors driving individuals' behaviour in various fields such as health related issues [24-26], consumption [27,28] or blood [29], organ [30] and body [31] donations, to name but a few.

Regarding sustainability and the environment, the TPB has been successfully applied in identifying the factors that determine sustainable behaviour in various fields: (a) Reducing contamination and natural resource conservation, such as the intentions to adopt a search engine that promotes sustainable water management [32], using biodiesel by car drivers [33] reducing fine particulate matter emissions [34] and willingness to pay for air quality improvement [35]; (b) recycling and reusing, such as people's intention to separate waste at home [36], reducing waste [37], recycling plastic waste [38], paper waste [39], electrical and electronic waste [40] and industry intentions to recycle food waste [41]; (c) purchasing intention of green products [42], traceable products [43], choosing a sustainable restaurant [15] and staying in green hotels [44].

Another very relevant line of research in the field of the environment is the extent to which environmental concerns influences sustainable behaviour. The role of environmental awareness is not conclusive. [45] find that even though environmental concerns are directly related to attitudes, egoistic concerns are the strongest predictor of attitudes. In the same line, [46] state that environmental education can assist in fostering pro-environmental behaviour, but this alone is not enough. In their case, social norms have a stronger influence on behavioural intentions than attitudes. [47] conclude that the more one has an affective connection with the natural environment, the greater one's intention to engage with it. And, what it is more important, rural participants report more positive affective connections and stronger behavioural intentions about engaging with the natural environment than urban participants. [48] study the environmental activism and confirm that rural residents engage in environmental activism against mining mostly in the form of complaining to government activities.

However, until now only a relatively small number of studies [16,19,49-52], applied to Australia, England, Australia, Pakistan, Malaysia and Canada, respectively (for more details of the results of those papers, see Discussion section), have examined the ETPB in the context of altruistic donations of money. Thus, this analysis contributes to expand the scarce literature that studies the intention to donate money through ETPB model; and what is more, this is the first time that this model is applied to the intention to donate money for sustainable rural development projects. Figure 1 summarises the basic structure of the ETPB model applied. 


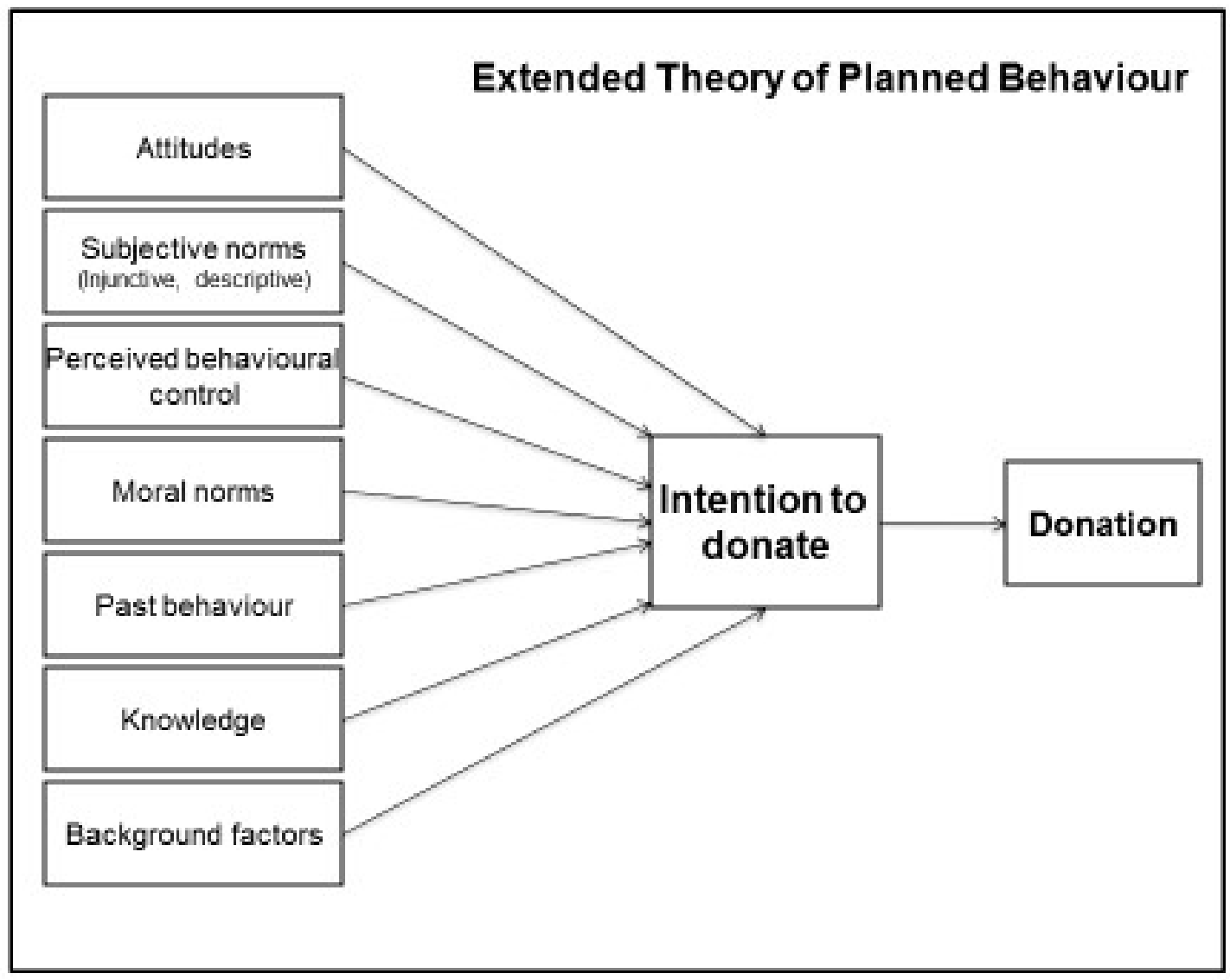

Figure 1. Theoretical framework explaining intention to donate for sustainable rural development. (Source: own elaboration.).

\section{Material and Methods}

Information to apply the theoretical model depicted in Figure 1 was collected through a $100 \%$ online survey. The questionnaire was structured in three parts. The first part included questions related to general knowledge on altruistic behaviours and crowdfunding. The second part contained questions on intentions to donate altruistically to finance projects for sustainable rural development. Finally, the third part gathered information on socio-demographics and other personal characteristics. All of the questions were asked in order to provide meaningful responses on attitudes, subjective norms, PBC, moral norms, past behaviour, knowledge and background characteristics. Before the final questionnaire was administrated, a pilot survey was undertaken on a small sample of respondents $(\mathrm{N}=20)$ to check for understanding of the questionnaire and interview length. Since knowledge about crowdfunding to fund small projects for sustainable rural development was found to be limited, a brief text with neutral information was included in the survey to be read by interviewees before filling out the questionnaire.

The questionnaire was developed following the general guidelines stated by [53] and previous empirical papers on pro-altruistic related behaviours. Unless stated otherwise, all items used a standard definition of donating behaviour and were assessed on a 5-point Likert scale (easier for respondents to deal with than 7-9 scales even if some variance is lost). Several constructs were measured on multi-item scales. To reduce the effects of response bias, some of the questions were asked in a negative way, which was reversed prior to scale construction. Items were ordered randomly throughout the questionnaire.

Intention to donate (ITD). Individuals responded to the following question: 'Are you willing to make a small donation to a sustainable rural development project that deals with an issue that matters you?' (1 definitely yes, 5 definitely no; the scale was inverted for the analysis). 
Attitude. The measure of attitude was averaged with three different questions: 'Donating money to small rural projects through crowdfunding increases the welfare of who does', 'I am in favour of participating in the financing of small rural projects through crowdfunding' and 'It is useful to donate money to small rural development projects through crowdfunding' (1 strongly disagree, 5 strongly agree).

Injunctive norms. We try here to learn if respondents have a social pressure to contribute altruistically to pro-rural development projects. The direct measure of injunctive norms was an average of the answers to the following two questions: 'My friends and family think that I should already have participated in some crowdfunding practice' and 'I believe that my family and friends expect me to donate money to small projects through fund-funding in the short term' (1 strongly disagree, 5 strongly agree).

Descriptive norms. Considering the pressure in the social environment of the interviewee, the descriptive norms were measured with the question: 'It is very likely that my family and friends donate money to small projects in the short term' (1 strongly disagree, 5 strongly agree).

Perceived Behavioural Control (PBC) is measured by a question where the respondents are asked to indicate their level of agreement about whether the decision to contribute altruistically to sustainable rural development projects depends on themselves: 'The decision to donate money to small projects through crowdfunding depends only on me' ( 1 strongly disagree, 5 strongly agree).

Moral norms have been measured by asking the interviewee if he/she thinks he/she should make a donation: 'I think that in the short term I should make a donation through crowdfunding' (1 strongly disagree, 5 strongly agree).

Past behaviour. Past experience in financing projects by crowdfunding has been measured by the question: 'Have you ever donated money to social or environmental organisations whose objectives are to raise funds for altruistic purposes?' (1 yes, 0 no).

Knowledge: Self-reported knowledge was obtained by asking the interviewee 'Could you indicate your level of knowledge about crowdfunding?' (1 high, 4 null; the scale was inverted for the analysis).

Background effects: Respondents were asked to provide information regarding their gender, age, marital status, household size, educational level, employment condition, place of residence and income.

Empirical information was collected from 280 individuals, between 20 and 78 years old, through a survey carried out in Spain between autumn 2016 and spring 2017. This sample size has a margin of error of $5.8 \%$ ( $\mathrm{pq}=0.5$ and a $95 \%$ confidence level). Most of the individuals were recruited through a non-profit private foundation specialized in citizen research, and the rest through the researchers' social networks. In all cases, the questionnaire was anonymous. At first, the sample reached 400 but some of them were poorly completed so that the sample was reduced to 280 .

Table 1 reports the variables and personal characteristics of the sample. Males were $45.7 \%$ of respondents; the average age was about 47 years (standard deviation (SD) 13.8); $43.2 \%$ of the sample were married and lived in households of 2.6 members, on average. Average household income per capita was $€ 1,300$ per month. Around $58 \%$ of respondents were residents of Aragón, the region where the study was undertaken, and the remaining were individuals from all over Spain (near half of them from the two most populated Spanish provinces: Madrid and Barcelona). On the other hand, $80 \%$ of the individuals live in urban areas. Most of the interviewees had a university degree $(68.2 \%)$, well above the Spanish average. This can be explained by the fact that only people over 20 years old and regular users of email were interviewed. Another factor was that people with higher levels of income and education are more prone to using the Internet and to participating in online studies such as this. They also have greater concern for social and rural problems. From the employment perspective, unemployed people represented only $7.8 \%$ of the interviewees, well below the rate of Spain in 2017 that reached $19.6 \%$.

In the literature, different techniques have been used to analyse individual's behaviour in accordance with the ETPB in many different areas of knowledge. The few studies that have examined the intention to donate money in an altruistic manner are based on hierarchical multiple regression 
(HMR) analysis. We followed this methodological approach to analyse the factors affecting the intention to donate altruistically for sustainable rural development.

Table 1. Socioeconomic variables of the sample and in Spain.

\begin{tabular}{cccc}
\hline Variable & Definition & Sample Value & Spain Value \\
\hline Gender & MALE (dummy) & $45.7 \%$ & $49.0 \%$ \\
\hline Age (average from total sample) & AGE (continuous) & 47.3 years & 43.9 years \\
\hline Marital status & MARRIED (dummy) & $43.2 \%$ & $43.7 \%$ \\
\hline $\begin{array}{c}\text { Household size (number of people } \\
\text { average) }\end{array}$ & HOUSEH (continuous) & 2.6 people & 2.5 people \\
\hline $\begin{array}{c}\text { Household monthly per capita } \\
\text { income }\end{array}$ & INCOME (dummy; $1=>1300 € ; 0$, & $36.4 \%$ & N.A. \\
\hline Region of residence & ARAGON (dummy) & $58.2 \%$ & $41.7 \%$ \\
\hline Education & Primary studies & $4.3 \%$ & $22.5 \%$ \\
\cline { 2 - 4 } & Secondary studies & $27.5 \%$ & $35.8 \%$ \\
\hline Employment condition & University degree & $68.2 \%$ & $19.6 \%$ \\
\hline
\end{tabular}

The dependent variable of the model (ITD) and most of the independent variables (attitudes, injunctive norms, descriptive norms, $\mathrm{PBC}$, moral norms and knowledge) are discrete variables. As noted, respondents were asked to indicate their agreement or disagreement with the different statements using Likert scales. The questions about past behaviour and employment condition were posed in a dichotomous way (yes or no), and age was a continuous variable. To explain the intention to donate, a theoretical HMR model was specified by (1), and their parameters were estimated by using STATA 14.2.

$$
\begin{gathered}
\text { ITD }=\beta_{0}+\beta_{1} \text { ATTITUDE }+\beta_{2} I N J U N C T I V E \_N+\beta_{3} D E S C R I P T I V E \_N+\beta_{4} P B C+ \\
\beta_{5} \text { MORAL_N }+\beta_{6} \text { PAST_BEHAVIOUR }+\beta_{7} \text { KNOWLEDGE } \\
+ \text { BACKGROUND_FACTORS }+u
\end{gathered}
$$

\section{ETPB Intention to Donate Results}

Descriptive statistics including means, standard deviations and bivariate correlations among the extended TPB variables are presented in Table 2.

Table 2 shows low correlations between predictor variables, and we can assume that discriminant validity exists, as is needed to have confidence in the subsequent analysis. Assessed on 1-5 scales, means of PBC (4.38), attitude (3.92) and knowledge (2.42) reflect that individuals have a positive intention towards pro-rural giving. Descriptive_n (2.45), Moral_n (2.26) and Injunctive_n (2.14) show that individuals are influenced by any kind of norms, either social or personal. 
Table 2. Descriptive data for the ETPB constructs included in regression analysis (means, SD and bivariate correlations. Cronbach's alpha coefficients in parenthesis).

\begin{tabular}{|c|c|c|c|c|c|c|c|c|c|c|c|}
\hline Variable & Mean & SD & 1 & 2 & 3 & 4 & 5 & 6 & 7 & 8 & 9 \\
\hline 1. Attitude & 3.92 & 0.72 & $(0.48)$ & & & & & & & & \\
\hline 2. Injunctive Norms & 2.14 & 0.90 & $0.268^{* * *}$ & $(0.48)$ & & & & & & & \\
\hline 3. Descriptive Norms & 2.45 & 1.08 & $0.202^{* * *}$ & $0.529^{* * *}$ & $(0.49)$ & & & & & & \\
\hline 4. РBC & 4.38 & 0.98 & $0.208^{* * *}$ & -0.056 & 0.006 & $(0.54)$ & & & & & \\
\hline 5. Moral Norms & 2.26 & 1.18 & $0.221^{* * *}$ & $0.361^{* * *}$ & $0.292 * * *$ & -0.080 & $(0.50)$ & & & & \\
\hline 6. Past Behaviour & 0.68 & 0.47 & $0.165^{* * *}$ & 0.082 & $0.120 * *$ & $0.130^{* *}$ & $0.114^{*}$ & $(0.47)$ & & & \\
\hline 7. Knowledge & 2.42 & 1.11 & $0.287^{* * *}$ & -0.015 & 0.018 & $0.187^{* * *}$ & -0.046 & $0.277^{* * *}$ & $(0.50)$ & & \\
\hline 8. Employment & 0.72 & 0.45 & -0.069 & 0.004 & -0.099 * & $0.107^{*}$ & 0.037 & $0.191^{* * *}$ & $0.217^{* * *}$ & $(0.56)$ & \\
\hline 9. Age & 47.36 & 13.81 & -0.048 & 0.055 & 0.048 & 0.058 & $0.139 * *$ & $0.208^{* * *}$ & 0.081 & -0.091 & $(0.55)$ \\
\hline
\end{tabular}

***,** and ${ }^{*}$ denote statistical significance at $1 \%, 5 \%, 10 \%$ level of significance, respectively. 
The results of the HMR model are shown in Table 3 (panels a and b). As this table shows, the variable Descriptive_n and many background factors were not found statistically significant (living in rural areas, region of residence, gender, marital status, household size, household monthly per capita income, education) so they were dropped from the regression analysis. The constructs of attitude, injunctive norms and PBC were first entered into the model. Next, moral norms were included. In the next step, past behaviour followed by knowledge were considered. Finally, background variables such as employment condition and age were considered into the analysis. The intention to donate to sustainable rural development projects in Spain is positively related to the constructs of the standard TPB model (attitudes accounts for the $16.8 \%$ of the variance and injunctive norms and PBC, account for $2.3 \%$ each one). These constructs jointly explain $21.4 \%$ of the variance. The positive and statistically significant sign on the coefficients for these variables indicates that: (1) People believe altruism is useful for supporting rural development projects; (2) they have a social pressure to donate, but (3) the decision to donate altruistically depends on themselves. Regarding additional constructs of the model, moral norms increase the variance explained by $2.4 \%$, while past behaviour and self-knowledge increase it by $5.3 \%$ and $6.2 \%$, respectively. Finally, the two socio-demographic variables that have been statistically significant at $10 \%$ (employment condition and age) only increase the variance explained by $1.4 \%$. With all significant variables in the equation, the ETPB model accounted for $36.8 \%$ of intentions to donate.

Table 3. Results of hierarchical multiple regression on intention to donate.

\begin{tabular}{|c|c|c|c|c|c|}
\hline \multicolumn{6}{|c|}{ Panel a } \\
\hline & Coefficient & Coefficient & $t$ & $P>(t)$ & Standard $\beta$ \\
\hline 1. Attitude & 0.291 & 0.089 & 3.27 & 0.001 & $0.168^{* * *}$ \\
\hline 2. Injunctive Norms & 0.191 & 0.065 & 2.96 & 0.003 & $0.139 * * *$ \\
\hline 3. $\mathrm{PBC}$ & 0.174 & 0.075 & 2.33 & 0.021 & $0.138^{* *}$ \\
\hline 4. Moral Norms & 0.207 & 0.052 & 3.95 & 0.000 & $0.198^{* * *}$ \\
\hline 5. Past Behaviour. & 0.538 & 0.151 & 3.56 & 0.000 & $0.204^{* * *}$ \\
\hline 6. Knowledge & 0.336 & 0.073 & 4.6 & 0.000 & $0.301^{* * *}$ \\
\hline $\begin{array}{l}\text { 7. Employment } \\
\text { condition }\end{array}$ & -0.286 & 0.144 & -1.99 & 0.048 & $-0.104^{* *}$ \\
\hline 7. Age & -0.008 & 0.005 & -1.81 & 0.071 & $-0.092 *$ \\
\hline Constant $\left(\beta_{0}\right)$ & 0.398 & 0.458 & 0.87 & 0.385 & \\
\hline \multicolumn{6}{|c|}{ Panel b } \\
\hline Model & $\mathbf{R} 2$ & R2 Change & \multicolumn{2}{|c|}{ F Value } & F Change \\
\hline 1 & 0.168 & . & \multicolumn{2}{|c|}{62.136} & . \\
\hline 2 & 0.191 & 0.023 & \multicolumn{2}{|c|}{35.031} & 7.748 \\
\hline 3 & 0.214 & 0.023 & \multicolumn{2}{|c|}{24.425} & 8.188 \\
\hline 4 & 0.238 & 0.024 & \multicolumn{2}{|c|}{19.914} & 8.776 \\
\hline 5 & 0.292 & 0.053 & \multicolumn{2}{|c|}{24.472} & 20.684 \\
\hline 6 & 0.353 & 0.062 & \multicolumn{2}{|c|}{25.923} & 26.073 \\
\hline 7 & 0.368 & 0.014 & \multicolumn{2}{|c|}{20.184} & 3.084 \\
\hline
\end{tabular}

$* * *, * *$ and $*$ denote statistical significance at $1 \%, 5 \%, 10 \%$ level of significance, respectively.

\section{Discussion}

In this paper we have used an ETPB model to explain the factors that influence the intention to donate money for sustainable rural projects. This model was able to explain almost $37 \%$ of the variance in people's intention to finance such projects, less than the models found in the literature for money donation with charity purposes. Attitude, injunctive norms, PBC, moral norms, past behaviour, knowledge, employment condition and age are significant predictors. All of them combined provide some support for the hypothesised relationships between the ETPB model predictors and intention to donate money for sustainable rural projects in Spain. 
In the extant literature, the TPB model has been successfully applied to predict the intention to donate money to charity and to social activities. However, to our knowledge, this is the first time it has been applied to pro-rural sustainable development projects. Nonetheless, in order to discuss our results, a comparison with the above mentioned works could be useful. The results of the papers reviewed are summarised in Table 4.

Table 4. TPB in charitable giving model comparison.

\begin{tabular}{|c|c|c|c|c|c|c|}
\hline & $\begin{array}{c}{[16]} \\
\text { Smith \& } \\
\text { McSweeney } \\
(2007)\end{array}$ & $\begin{array}{c}{[19]} \\
\text { van der } \\
\text { Linden } \\
(\mathbf{2 0 1 1})\end{array}$ & $\begin{array}{c}{[49]} \\
\text { Knowles et al. } \\
\text { (2012) }\end{array}$ & $\begin{array}{c}{[50]} \\
\text { Kashif \& De } \\
\text { Run (2015) }\end{array}$ & $\begin{array}{c}{[51]} \\
\text { Kashif et al. } \\
\quad(2015)\end{array}$ & $\begin{array}{c}{[52]} \\
\text { Mittleman \& } \\
\text { Rojas-Méndez } \\
\text { (2018) }\end{array}$ \\
\hline & Australia & England & Australia & Pakistan & Malaysia & Canada \\
\hline $\mathrm{R} 2$ & 0.67 & 0.68 & 0.61 & 0.63 & & 0.76 \\
\hline Attitude & $0.11 *$ & $0.21^{* * *}$ & $0.32 * * *$ & $0.43^{* * *}$ & 0.01 & Yes/No* \\
\hline $\begin{array}{l}\text { Descriptive } \\
\text { Norms }\end{array}$ & - & -0.16 & \multirow[t]{2}{*}{0.01} & $0.04^{* * *}$ & 0.13 & \multirow[t]{2}{*}{0.03} \\
\hline $\begin{array}{l}\text { Injunctive } \\
\text { Norms }\end{array}$ & $0.13^{*}$ & 0.07 & & $0.26^{* * *}$ & $0.40^{* * *}$ & \\
\hline PBC & $0.24^{* * *}$ & $0.27^{* * *}$ & $0.31^{* * *}$ & $0.31 * *$ & -0.01 & $0.25^{* * *}$ \\
\hline $\begin{array}{l}\text { Moral } \\
\text { Norms }\end{array}$ & $0.15^{* * *}$ & $0.51^{* * *}$ & $0.23^{* * *}$ & $0.34^{* *}$ & -0.14 & $0.25^{* * *}$ \\
\hline $\begin{array}{c}\text { Past } \\
\text { Behaviour. }\end{array}$ & $0.54^{* * *}$ & $0.49^{* * *}$ & $0.19^{* * *}$ & $0.29 * *$ & $0.49^{* * *}$ & $0.27^{* * *}$ \\
\hline
\end{tabular}

After attitude explained $16.8 \%$ of the variance in the model, knowledge on crowdfunding as a tool to donate was our second predictor of future behaviour which increased explained variance by $6.2 \%$, followed by past behaviour, explaining $5.3 \%$. It is remarkable that the last two more significant indicators are not in Ajzen's basic TPB model. Besides, moral norms, PBC and injunctive norms contribute less to the explained variance of the model $(2.4 \%, 2.3 \%$ and $2.3 \%$, respectively).

One of the variables that most contribute to predict intention to donate is attitude [52]. Attitude can be split into three dimensions: Attitude towards donation (the act of giving), towards helping others and towards charitable organisations (object). They underscore the importance of defining this construct in a multidimensional manner, although a single measure of attitude has proved to be a good predictor in $[16,19,49,50]$. In our case, we asked two questions related to the attitude towards the act of giving money and one more question over the attitude towards the object-small rural projects. The three combined are the predictor that contributes the most to explain the variance (at $16.8 \%$ ). To add predicted power, being more precise in the question about attitude (by adding that this kind of rural initiative sets population, improves biodiversity, avoids land abandonment and preserves the landscape) could improve our model in the future. Even though in [18] attitude towards the object (charitable organisations) turns out to be non-significant, the good consequences of promoting rural projects are less well known than those of charities and are more concrete.

Regarding past behaviour, [16,52] report that it predicts even better than other constructs such as attitude or PBC. In general, it is also a good predictor of the intention to donate blood, time or money. In our case, past behaviour contributes less than attitude and knowledge, increasing the explained variance by $5.3 \%$.

Apart from that, we found moral norms to be a significant and positive predictor-although its contribution to the explained variance again only amounted up to $2.4 \%$. Our result corroborates the hypothesis related to using it as an independent predictor of other norms (i.e., subjective). This was also validated by $[16,19,49,52]$.

Following the extant literature, we split subjective norms into descriptive and injunctive. Similar to [16], descriptive norms were not significant; but injunctive norms, despite being highly 
significant, only explained $2.3 \%$ of the variance. [51] suggest that there are differences between countries because people behave differently depending on whether their culture is individualistic or collectivist. In the first case, attitude is found as a good predictor, whereas in the last case, people are strongly influenced by members of a reference group, and subjective norms (both injunctive and descriptive) are better predictors. [50] analysed Pakistan as an example of a collectivist country and confirm that both constructs are significant.

In our case, the Hofstede individualism score [54] for Spain is smaller compared to countries where subjective norms (whether split or not) are not significant: Australia (90) [49], Canada (80) [52], and United Kingdom (89) [19], but very high comparing with countries that used to be considered as collectivist and therefore Hofstede score is small: Malaysia (26) [51] and Pakistan (14) [50]. Spain, having an index 51, behaves as the group of individualistic countries [54].

Finally, the most striking result is that background factors (employment condition and age) are significant but negatively, meaning that young and unemployed persons are more prone to donating to pro-rural initiatives. Firstly, this could be explained by the fact that young people are more often Internet users, therefore they are more familiar with the crowdfunding mechanism and according to [55,56], online fundraising might encourage young donors. Secondly, in some way, the young and unemployed seem to be more concerned with sustainable rural projects (empathy concern positively affects the donation decision, [57]). On the one hand, following [58], the variable that negatively affects charitable giving is money perceptions (feelings of retention and inadequacy) and not individual's income. Unemployed young Spaniards living with their parents may not have the feeling of a lack of money. Finally, it would appear that, due to their personal condition, they perceive the relationship between those projects, creating jobs, as well as the settlement of population in rural areas, as important. Moreover, although a positive sign was expected, it is certain that it depends on the context: For instance, [59] analysed Hurricane Katrina and found that even poor people will donate to charity to help those who are needy. Mutatis mutandis: something like this may be also true in our field of research.

We have proved that the predictors used under the extended TPB model to document the intention to donate to charity are also significant in predicting the intention to donate to sustainable pro-rural projects. Nevertheless, in the latter, the explanatory power of those variables is smaller: The adjusted $R$-squared in the reviewed literature are between 0.65 and 0.75 , whereas we obtained 0.37 . To improve the explanatory power of this model, more research should be undertaken. First, as stated above, using a multi-dimensional construct for attitudes regarding donating to sustainable pro-rural projects, in addition to charities, could make the model better. Apart from the variant object of the donation, another explanation of the low explanatory power of our model could be found in the lack of habit in Spanish culture to donate, and the impression that we already pay taxes and the government should be in charge of implementing these initiatives. Therefore, even if attitude and moral norms are significant, and also injunctive norms and PBC—although at a lower level—in the end people wait for the government to step in instead of donating money. Moreover, Spanish society faces serious social problems such as political refugees, sub-Saharan immigrants, and local starvation. Probably interviewees are more prone to donating in favour of those social problems than in favour of sustainable rural development projects.

Finally, qualitative information gathered through semi-structured interviews could help to figure out what other predictors are behind the donors' behaviour.

\section{Conclusions}

The aim of this paper has been to analyse the extent to which private money donations can contribute to the objectives set by the Rural Development Programmes of the EU Common Agricultural Policy (CAP) for 2014-2020. Under the CAP frame, public expenditures finance projects to maintain territorial balance. 
On the other hand, sometimes private initiative contributes to this purpose by financing small projects. The frequency and quantity of donations vary among countries depending on their culture. Even in countries like Spain, where taxes are high and citizens rely on Government for these tasks, small projects often are underfunded publicly and are better financed by donations. This is the case of the type of pro-rural projects we have considered.

In order to promote the financing of this kind of project, the predictors of intention to donate have been elicited using the Extended Theory of Planned Behaviour model. To the best of our knowledge, this is the first time this theoretical model has been applied to pro-rural development projects.

We have concluded that attitude, crowdfunding knowledge as a tool to finance, past behaviour, followed distantly by moral norms, injunctive norms and past behavioural control help to explain the intention to donate to the projects studied in this work. Since those projects contribute to maintain territorial balance, the improvement of altruistic behaviour may complement public policy in financing the sustainability of rural areas. For this purpose, it would be necessary to carry out a pedagogical work to make known the crowdfunding and its usefulness for financing these kinds of projects.

Finally, this paper has limitations that have to be taken into account and constitute further research avenues on the topic. First, the size or our sample has to be enlarged and has to better represent the whole Spanish population. In order to obtain a better understanding of the underlying reasons to donate to sustainable pro-rural projects, a qualitative analysis of the motivations of this population behind their decisions is needed.

Author Contributions: Conceptualization, L.P.P. and P.E.; Formal analysis, L.P.P. and P.E.; Investigation, L.P.P.; Resources, P.E.; Software, L.P.P.; Supervision, P.E.; Writing—original draft, L.P.P. and P.E. Both authors read and approved the final manuscript.

Funding: This research was funded by "Private, social and environmental profitability of traditional low-yielding olive groves in Teruel (Spain)" (Project R+D PLATEA FITE 2016-A.13) and the regional Government of Aragon (Research Group “Economía Agroalimentaria y de los Recursos Naturales) who financed the publication of the paper.

Acknowledgments: The authors thank Tiziana de Magistris for their assistance in preparing the questionnaire used in the survey.

Conflicts of Interest: The authors declare no conflict of interest. Those funding the study had no role in its design, in the collection, analyses or interpretation of data, in the writing of the manuscript or in the decision to publish the results.

\section{References}

1. Ajzen, I. The theory of planned behavior. Organ. Behav. Hum. Decis. Process. 1991, 50, 179-211. [CrossRef]

2. Fishbein, M. The relationship between beliefs, attitudes, and behavior. In Cognitive Consistency; Feldman, S., Ed.; Academic Press: New York, NY, USA, 1966; ISBN 978-1483251530.

3. Fishbein, M.; Ajzen, I. Belief, Attitude, Intention, and Behavior: An Introduction to Theory and Research; Addison-Wesley: Boston, MA, USA, 1975; ISBN 0-201-02089-0.

4. Ajzen, I.; Fishbein, M. Attitude-behavior relations: A theoretical analysis and review of empirical research. Psychol. Bull. 1977, 84, 888-918. [CrossRef]

5. Ajzen, I. Attitudes, Personality and Behavior; Dorsey: Chicago, IL, USA, 1988; ISBN 978-335217038.

6. Ajzen, I. Nature and operation of attitudes. Annu. Rev. Psychol. 2001, 52, 27-58. [CrossRef] [PubMed]

7. Madden, T.J.; Ellen, P.S.; Ajzen, I. A comparison of the theory of planned behavior and the theory of reasoned action. Personal. Soc. Psychol. Bull. 1992, 18, 3-9. [CrossRef]

8. Fishbein, M.; Ajzen, I. Predicting and Changing Behavior: The Reasoned Action Approach; Psychology Press: New York, NY, USA, 2010; ISBN 1138995215.

9. Armitage, C.J.; Conner, M. Efficacy of the theory of planned behaviour: A meta-analytic review. Br. J. Soc. Psychol. 2001, 40, 471-499. [CrossRef] [PubMed]

10. Ajzen, I. Perceived behavioral control, self-efficacy, locus of control, and the theory of planned behavior. J. Appl. Soc. Psychol. 2002, 32, 665-683. [CrossRef] 
11. Ajzen, I. The theory of planned behaviour: Reactions and reflections. Psychol. Health 2011, 26, $1113-1127$. [CrossRef] [PubMed]

12. Teo, T.; Zhou, M.; Noyes, J. Teachers and technology: Development of an extended theory of planned behavior. Educ. Technol. Res. Dev. 2016, 64, 1033-1052. [CrossRef]

13. Wang, S.; Fan, J.; Zhao, D.; Yang, S.; Fu, Y. Predicting consumers' intention to adopt hybrid electric vehicles: Using an extended version of the theory of planned behavior model. Transportation 2016, 43, 123-143. [CrossRef]

14. Karimy, M.; Zareban, I.; Araban, M.; Montazeri, A. An extended theory of planned behavior (TPB) used to predict smoking behavior among a sample of Iranian medical students. Int. J. High Risk Behav. Addict. 2015, 4, 3. [CrossRef]

15. Tommasetti, A.; Singer, P.; Troisi, O.; Maione, G. Extended Theory of Planned Behavior (ETPB): Investigating Customers' Perception of Restaurants' Sustainability by Testing a Structural Equation Model. Sustainability 2018, 10, 2580. [CrossRef]

16. Smith, J.; McSweeney, A. Charitable giving: The effectiveness of a revised theory of planned behaviour model in predicting donating intentions and behavior. J. Community Appl. Soc. Psychol. 2007, 17, 363-386. [CrossRef]

17. Conner, M.; Armitage, C.J. Extending the theory of planned behavior: A review and avenues for further research. J. Appl. Soc. Psychol. 1998, 28, 1429-1464. [CrossRef]

18. Manstead, A.S.R. The role of moral norm in the attitude-behavior relation. In Attitudes, Behavior, and Social Context; Terry, D.J., Hogg, M.A., Eds.; Lawrence Erlbaum: Mahwah, NJ, USA, 2000; pp. 11-30. ISBN 9781135685881.

19. Van der Linden, S. Charitable intent: A moral or social construct? a revised Theory of Planned Behavior model. Curr. Psychol. 2011, 30, 355-374. [CrossRef]

20. Rise, J.; Sheeran, P.; Hukkelberg, S. The role of self-identity in the theory of planned behaviour: A meta-analysis. J. Appl. Soc. Psychol. 2010, 40, 1085-1105. [CrossRef]

21. Farizo, B.A.; Oglethorpe, D.; Soliño, M. Personality traits and environmental choices: On the search for understanding. Sci. Total Environ. 2016, 566, 157-167. [CrossRef] [PubMed]

22. Soliño, M.; Farizo, B.A. Personal traits underlying environmental preferences: A discrete choice experiment. PLoS ONE 2014, 9, e89603. [CrossRef] [PubMed]

23. Lane, B.; Potter, S. The adoption of cleaner vehicles in the UK: Exploring the consumer attitude-action gap. J. Clean. Prod. 2007, 15, 1085-1092. [CrossRef]

24. Menozzi, D.; Sogari, G.; Mora, C. Explaining vegetable consumption among young adults: An application of the theory of planned behaviour. Nutrients 2015, 7, 7633-7650. [CrossRef] [PubMed]

25. Flowers, E.P.; Freeman, P.; Gladwell, VF. The development of three questionnaires to assess beliefs about green exercise. Int. J. Environ. Res. Public Health 2017, 14, 172. [CrossRef]

26. Manyaapelo, T.; Nyembezi, A.; Ruiter, R.A.C.; van den Borne, B.; Sifunda, S.; Reddy, P. Understanding the psychosocial correlates of the intention to use condoms among young men in kwazulu-natal, South Africa. Int. J. Environ. Res. Public Health 2017, 14, 339. [CrossRef] [PubMed]

27. Moons, I.; De Pelsmacker, P. An extended decomposed theory of planned behaviour to predict the usage intention of the electric car: A multi-group comparison. Sustainability 2015, 7, 6212-6245. [CrossRef]

28. Qi, X.; Ploeger, A. Explaining consumers' intentions towards purchasing green food in Qingdao, China: The amendment and extension of the theory of planned behavior. Appetite 2019, 133, 414-422. [CrossRef]

29. Chen, L. Applying the extended theory of planned behaviour to predict Chinese people's non-remunerated blood donation intention and behaviour: The roles of perceived risk and trust in blood collection agencies. Asian J. Soc. Psychol. 2017, 20, 221-231. [CrossRef]

30. Hyde, M.K.; Knowles, S.R.; White, K.M. Donating blood and organs: Using an extended theory of planned behavior perspective to identify similarities and differences in individual motivations to donate. Health Educ. Res. 2013, 28, 1092-1104. [CrossRef] [PubMed]

31. Delaney, M.F.; White, K.M. Predicting peoples intention to donate their body to medical science and research. J. Soc. Psychol. 2015, 155, 221-237. [CrossRef] [PubMed]

32. Reyes-Menendez, A.; Saura, J.R.; Palos-Sanchez, P.R.; Álvarez-García, J. Understanding User Behavioral Intention to Adopt a Search Engine that Promotes Sustainable Water Management. Symmetry 2018, 10, 584. [CrossRef] 
33. Gracia, A.; Barreiro-Hurlé, J.; Pérez y Pérez, L. Overcoming the barriers for biodiesel use in Spain: An analysis of the role of convenience and price. J. Clean. Prod. 2018, 172, 391-401. [CrossRef]

34. Ru, X.; Qin, H.; Wang, S. Young people's behaviour intentions towards reducing PM2.5 in China: Extending the theory of planned behaviour. Resour. Conserv. Recycl. 2019, 141, 99-108. [CrossRef]

35. Fu, B.; Kurisu, K.; Hanaki, K.; Che, Y. Influential factors of public intention to improve the air quality in China. J. Clean. Prod. 2019, 209, 595-607. [CrossRef]

36. Xu, L.; Ling, M.; Lu, Y.; Shen, M. Understanding household waste separation behaviour: Testing the roles of moral, past experience, and perceived policy effectiveness within the theory of planned behaviour. Sustainability 2017, 9, 625. [CrossRef]

37. Whitmarsh, L.E.; Haggar, P.; Thomas, M. Waste Reduction Behaviors at Home, at Work, and on Holiday: What Influences Behavioral Consistency Across Contexts? Front. Psychol. 2018, 9, 2447. [CrossRef] [PubMed]

38. Khan, F.; Ahmed, W.; Najmi, A. Understanding consumers' behavior intentions towards dealing with the plastic waste: Perspective of a developing country. Resour. Conserv. Recycl. 2019, 142, 49-58. [CrossRef]

39. Cheung, S.F.; Chan, D.K.S.; Wong, Z.S.Y. Reexamining the theory of planned behavior in understanding wastepaper recycling. Environ. Behav. 1999, 31, 587-612. [CrossRef]

40. Kumar, A. Exploring young adults' e-waste recycling behaviour using an extended theory of planned behaviour model: A cross-cultural study. Resour. Conserv. Recycl. 2019, 141, 378-389. [CrossRef]

41. Mark, T.M.W.; Yu, I.K.M.; Tsang, D.C.W.; Hsu, S.C.; Poon, C.S. Promoting food waste recycling in the commercial and industrial sector by extending the Theory of Planned Behaviour: A Hong Kong case study. J. Clean. Prod. 2018, 204, 1034-1043. [CrossRef]

42. Maichum, K.; Parichatnon, S.; Peng, K.C. Application of the extended theory of planned behavior model to investigate purchase intention of green products among Thai consumers. Sustainability 2016, 8, 1077. [CrossRef]

43. Spence, M.; Stancu, V.; Elliott, C.T.; Dean, M. Exploring consumer purchase intentions towards traceable minced beef and beef steak using the theory of planned behavior. Food Control 2018, 91, 138-147. [CrossRef]

44. Liu, T.; Jin, S.; Zhu, H.; Qi, X. Construction of Revised TPB Model of Customer Green Be-havior: Environmental Protection Purpose and Ecological Values Perspectives. IOP Conf. Ser. Earth Environ. Sci. 2018, 167, 2021. [CrossRef]

45. De Groot, J.; Steg, L. General beliefs and the theory of planned behavior: The role of environmental concerns in the TPB. J. Appl. Soc. Psychol. 2007, 7, 1817-1836. [CrossRef]

46. Fang, W.T.; Ng, E.; Wang, C.M.; Hsu, ML. Normative beliefs, attitudes, and social norms: People reduce waste as an index of social relationships when spending leisure time. Sustainability 2017, 9, 1696. [CrossRef]

47. Hinds, J.; Sparks, P. Engaging with the natural environment: The role of affective connection and identity. J. Environ. Psychol. 2008, 28, 109-120. [CrossRef]

48. Yang, X.; Ho, P. Conflict over mining in rural China: A comprehensive survey of intentions and strategies for environmental activism. Sustainability 2018, 10, 1669. [CrossRef]

49. Knowles, S.R.; Hyde, M.K.; White, K.M. Predictors of young people's charitable intentions to donate money: An extended Theory of Planned Behavior perspective. J. Appl. Soc. Psychol. 2012, 42, 2096-2110. [CrossRef]

50. Kashif, M.; De Run, E.C. Money donations intentions among Muslim donors: An extended theory of planned behavior model. Int. J. Nonprofit Volunt. Sect. Mark. 2015, 20, 84-96. [CrossRef]

51. Kashif, M.; Sarifuddin, S.; Hassan, A. Charity donation: Intentions and behaviour. Mark. Intell. Plan. 2015, 33, 90-102. [CrossRef]

52. Mittelman, R.; Rojas-Mendez, J. Why Canadians give to charity: An extended theory of planned behaviour model. Int. Rev. Public Nonprofit Mark. 2018, 15, 189-204. [CrossRef]

53. Ajzen, I. Theory of Planned Behaviour Questionnaire. Measurement Instrument Database for the Social Science. 2013. Available online: www.midss.ie (accessed on 21 November 2016).

54. Hofstede Insights. 2018. Available online: https://www.hofstede-insights.com/ (accessed on 23 July 2018).

55. Choi, S.; Kim, H.; Chung, M.; Lee, S.Y. Online Donation Experiences, Donation Awareness, and Intention of Future Donation Among Teenagers in South Korea. J. Soc. Serv. Res. 2018. [CrossRef]

56. Ahn, J.; Sura, S.; An, J. Intention to donate via social network sites (SNSs): A comparison study between Malaysian and South Korean users. Inf. Technol. People 2018, 31, 910-926. [CrossRef]

57. Verhaert, G.A.; Van den Poel, D. Empathy as added value in predicting donation behaviour. J. Bus. Res. 2011, 64, 1288-1295. [CrossRef] 
58. Wiepking, P.; Breeze, B. Feeling poor, acting stingy: The effect of money perceptions on charitable giving. Int. J. Nonprofit Volunt. Sect. Mark. 2012, 17, 13-24. [CrossRef]

59. Avdeyeva, T.V.; Burgetova, K.; Welch, I.D. To help or not to help? Factors that determined helping responses to Katrina victims. Anal. Soc. Issues Public Policy 2006, 6, 159-173. [CrossRef] 